\title{
Effect of Irrigation with Diluted Winery Wastewater on Phosphorus in Four Differently Textured Soils
}

\author{
A.R. Mulidzi ${ }^{*}$, C.E. Clarke $^{2}$, P.A. Myburgh ${ }^{1}$ \\ (1) Soil and Water Science Division, ARC Infruitec-Nietvoorbij, Private Bag X5026, Stellenbosch 7599, South Africa \\ (2) Department of Soil Science, Stellenbosch University, Private Bag X1, Matieland 7602, South Africa
}

Submitted for publication: December 2015

Accepted for publication: April 2016

Key words: Chemical oxygen demand, pot experiment, solubility, soil pH, water quality

\begin{abstract}
The wine industry needs solutions for wastewater treatment, as environmental legislation for its disposal is increasingly being enforced due to non-compliance. The feasibility of re-using diluted winery wastewater was assessed in a pot experiment under a rain shelter over four simulated irrigation seasons. Four soils varying in parent material and clay content, viz. aeolic sand from Lutzville containing $0.4 \%$ clay, alluvial sand from Rawsonville containing 3.3\% clay, granite-derived soil from Stellenbosch containing 13\% clay, and shale-derived soil from Stellenbosch containing $\mathbf{2 0 \%}$ clay, were irrigated with wastewater diluted to $3000 \mathrm{mg} / \mathrm{L}$ COD (chemical oxygen demand), whereas the control received municipal water. Irrigation with diluted winery wastewater increased the $\mathrm{pH}_{(\mathrm{KCl})}$ in the shale- and granite-derived soils into the optimum range for $P$ availability. Although $\mathrm{pH}_{(\mathrm{KCl})}$ in the aeolic sand was initially above the optimum range, relatively high $\mathrm{Na}^{+}$levels also caused available $\mathrm{P}$ to increase as the $\mathrm{pH}_{(\mathrm{KCl})}$ increased. The $\mathrm{pH}_{(\mathrm{KCl})}$ in the alluvial sand increased beyond the optimum range, thereby causing a reduction in the available $P$. This indicates that irrigation with diluted winery wastewater may only enhance $\mathrm{P}$ absorption if the $\mathrm{pH}_{(\mathrm{KCl})}$ shift is towards the optimum. It must be noted that the results represent a worst-case scenario, i.e. in the absence of rainfall or crops.
\end{abstract}

\section{INTRODUCTION}

Wineries generate large volumes of wastewater, and increased wine production in South Africa is exerting more pressure on natural resources. In many cases, winery wastewater is not suitable for the irrigation of agricultural crops (Mulidzi et al., 2009). Due to the intensification of environmental legislation (Department of Water Affairs, 2013), the wine industry is expected to find solutions for the treatment or re-use of winery wastewater (Van Schoor, 2001). This initiated the development of guidelines for the management of wastewater and solid waste at wineries (Van Schoor, 2005). A shortage of good-quality water leads to an increasing demand to irrigate with poor-quality water such as saline groundwater, drainage water and treated wastewater (Jalali et al., 2008). The negative effects of re-using untreated municipal and other industrial wastewater for agricultural irrigation are well documented (Bond, 1998; Papini, 2000; Mulidzi, 2001; Arienzo et al., 2009; Christen et al., 2010; Laurenson et al., 2012; Laurenson \& Houlbrooke, 2011; Mosse et al., 2011; Arienzo et al., 2012). The impact of irrigation with treated wastewater on the environment has not been investigated widely, although the demand for the use of sewage effluent due to water shortages is increasing (Walker \& Lin, 2008). The disposal of wastewater through land application has been practised for many years by the majority of wineries (Mulidzi, 2001; Laurenson \& Houlbrooke, 2011). Effective disposal of wastewater through re-use depends on the irrigation technology, as well as on soil properties (Oron et al., 1999). Furthermore, a study carried out in some of the South African grape-growing regions confirmed that the impact of using undiluted winery wastewater for irrigation differed substantially between soils (Mulidzi, 2001).

Most of the previous studies and reports focused on the negative effects of irrigating with winery wastewater on soil physical and chemical status (Bond, 1998; Arienzo et al., 2009; Christen et al., 2010; Mosse et al., 2011; Arienzo et al., 2012; Laurenson et al., 2012; Howell \& Myburgh, 2014). However, it has also been shown that re-using wastewater for irrigation and as fertiliser has positive effects, such as $\mathrm{pH}$ increases, water- and mineral salt-retention characteristics, as well as restoration and maintenance of soil micro-flora (Papini, 2000). It was also proposed that re-using potassium-rich wastewater could enhance soil fertility (Mosse et al., 2011). In this regard it is possible that phosphorus (P) applied via irrigation with winery wastewater could contribute to the nutrient requirements of agricultural crops. The solubility of phosphate $\left(\mathrm{PO}_{4}^{3-}\right)$ compounds, or $\mathrm{P}$

*Corresponding author: E-mail address: Mulidzir@arc.agric.za

Acknowledgements: The authors wish to thank the Water Research Commission, for initiating and funding the project; Winetech, THRIP (TP1208066038) and ARC Infruitec-Nietvoorbij, for co-funding; the staff of the Soil \& Water Science Division at ARC Infruitec-Nietvoorbij, for technical support; and in particular Mr Francois Baron, for his dedicated efforts. Any opinions, findings and conclusions or recommendations expressed in any publication generated through THRIP-supported research are those of the author(s) and therefore the NRF/THRIP will not accept any liability in that regard 
availability to plants ( $\mathrm{P}$ is adsorbed by plants in the ionic form $\mathrm{H}_{2} \mathrm{PO}_{4}^{-}$), strongly depends on the soil $\mathrm{pH}$ (Sharpley et al., 1988; Conradie, 1994; Busman et al., 2002; Devau et al., 2009). In acidic soils, particularly where $\mathrm{pH}$ (water) is less than 5.5, aluminium $\left(\mathrm{Al}^{3+}\right)$ and iron $\left(\mathrm{Fe}^{3+}\right)$ will react with $\mathrm{PO}_{4}^{3-}$ to form amorphous phosphates (Busman et al., 2002). The amorphous $\mathrm{Al}^{3+}$ and $\mathrm{Fe}^{3+}$ phosphates gradually change into insoluble $\mathrm{PO}_{4}^{3-}$ compounds that are not available to plants. Phosphate also becomes increasingly insoluble if the soil $\mathrm{pH}_{(\mathrm{KCl})}$ exceeds 7 (Conradie, 1994; Busman et al., 2002). In alkaline soils, i.e. $\mathrm{pH}>7$, calcium $\left(\mathrm{Ca}^{2+}\right)$ is the dominant cation that will react with $\mathrm{PO}_{4}^{3-}$, to form a general sequence of calcium phosphates, viz. dibasic calcium phosphate dihydrate, octocalcium phosphate and hydroxyl apatite (Busman et al., 2002). The formation of each of these compounds decreases the solubility of phosphate. On the other hand, $\mathrm{PO}_{4}^{3-}$ solubility can also increase in high $\mathrm{pH}$ soils when exchangeable sodium $\left(\mathrm{Na}^{+}\right)$releases inorganic $\mathrm{PO}_{4}^{3-}$ (Sharpley et al., 1988). When $\mathrm{Na}^{+}$replaces exchangeable $\mathrm{Ca}^{2+}, \mathrm{Mg}^{2+}$ and $\mathrm{Al}^{3+}$, the negative potential of the surface increases, which results in the desorption of $\mathrm{PO}_{4}^{3-}$ (Naidu $\&$ Rengasamy, 1993). It has also been reported that watersoluble $\mathrm{PO}_{4}^{3-}$ increases as $\mathrm{Na}^{+}$saturation increases in alkaline soils (Abrol et al., 1988 and references therein). Similar to the effect of exchangeable $\mathrm{Na}^{+}$, soluble $\mathrm{P}$ increased to above pH 7 when a silty clay soil was alkalinised with potassium hydroxide (KOH) (Devau et al., 2009). A number of field and laboratory studies have shown that irrigation with winery wastewater increases soil $\mathrm{pH}$, particularly if the water contains high levels of potassium $\left(\mathrm{K}^{+}\right)$and $\mathrm{Na}^{+}$(Lieffering \& McLay, 1996; Papini, 2000; Mulidzi, 2001; Laurenson et al., 2010; Laurenson \& Houlbrooke, 2011; Mulidzi et al., 2015). However, it was also reported that the opposite effect on soil pH is possible (Bueno et al., 2009). Therefore, the extent to which the $\mathrm{P}$ applied via winery wastewater can be absorbed by plants will depend indirectly on the effect of the wastewater irrigation on the soil $\mathrm{pH}$. However, this does not rule out the possibility that applied P may be lost by leaching during winter rainfall.

The objective of the study was to determine the effect of irrigation with diluted winery wastewater on $\mathrm{P}$ in four differently textured soils.

\section{MATERIALS AND METHODS \\ Experiment layout}

Four pedogenetically different soils from three grape-growing regions in the Western Cape were included in the study, viz. (i) aeolic sand from Lutzville containing $0.4 \%$ clay, (ii) alluvial sand from Rawsonville containing 3.3\% clay, (iii) granitederived soil from Stellenbosch containing 13\% clay, and (iv) shale-derived soil from Stellenbosch containing 20\% clay. The properties and characteristics of the soils were presented previously (Mulidzi et al., 2016). Bulked soil samples were collected from the topsoil layers, i.e. approximately 0 to $30 \mathrm{~cm}$ deep. Soils were packed into $3.54 \mathrm{dm}^{3} \mathrm{PVC}$ pots to a bulk density of $1400 \mathrm{~kg} / \mathrm{m}^{3}$, as described by Mulidzi et al. (2016). The pot experiment was carried out under a $20 \mathrm{~m}$ x $40 \mathrm{~m}$ translucent fibreglass rain shelter at ARC InfruitecNietvoorbij near Stellenbosch. Control treatments of all soils were irrigated with water supplied by the Stellenbosch municipality. The winery wastewater treatments were irrigated with wastewater diluted to a chemical oxygen demand (COD) of $3000 \mathrm{mg} / \mathrm{L}$, as described by Mulidzi et al. (2016). The undiluted wastewater was obtained from the wastewater collection pit at a winery near Rawsonville and transported in a tank to Stellenbosch. Treatments were applied over four simulated irrigation seasons consisting of six irrigations each. Consequently, a total of 24 irrigations were applied over the four simulated seasons. Details of the pot experiment layout and wastewater dilution procedure, as well as the irrigation system and irrigation scheduling, were presented earlier (Mulidzi et al., 2016).

\section{Analyses}

Water samples were collected and analysed prior to each irrigation. Phosphorus was not determined in the irrigation water. Triplicate soil samples were collected from the bulked soil to determine the initial soil chemical status. Due to destructive soil sampling, each experimental "plot" consisted of four pots. Following each simulated irrigation season, the soil in one of the pots was sampled, i.e. after six, 12,18 and 24 irrigations. Soil samples were taken from the 0 to $10 \mathrm{~cm}$ and 10 to $20 \mathrm{~cm}$ layers in the pots of all replications. Soil samples were air dried and passed through a $2 \mathrm{~mm}$ mesh sieve. The $\mathrm{P}$ and $\mathrm{pH}_{(\mathrm{KCl})}$ were determined by a commercial laboratory (BEMLAB, Strand). Phosphorus was determined according to the Bray No. 2 method, viz. extraction with 0.03 $\mathrm{M} \mathrm{NH}_{4} \mathrm{~F}$ (ammonium-fluoride) in $0.01 \mathrm{M} \mathrm{HCl}$ (hydrochloric acid). The $\mathrm{P}$ concentration in the extract was determined by inductively coupled plasma optical emission spectrometry (ICP-OES) using a spectrometer (PerkinElmer Optima 7300 DV, Waltham, Massachusetts). The $\mathrm{pH}_{(\mathrm{KCl})}$ was determined in a $1 \mathrm{M}$ potassium chloride $(\mathrm{KCl})$ suspension.

\section{Statistical procedures}

Each soil/water treatment was replicated four times in a completely randomised design. The four soils were randomly allocated within each block. The treatment design was a split-plot, with soil type as the main plot factor and soil depth as the sub-plot factor. Analyses of variance were performed separately for each season using SAS version 9.2 (SAS, 2008). The Shapiro-Wilk test was performed to test for non-normality (Shapiro \& Wilk, 1965). Student's " $t$ " least significant difference (LSD) was calculated at the 5\% significance level to facilitate comparison between treatment means (Ott, 1998).

\section{RESULTS AND DISCUSSION}

Some soil physical characteristics, as well as cation and $\mathrm{pH}_{(\mathrm{KCl})}$ responses of the four soils to irrigation with diluted winery wastewater, were presented previously (Mulidzi et al., 2015; 2016). The irrigation amounts applied to the Rawsonville sand, Lutzville sand and Stellenbosch shale soil were comparable (Table 1), but the Stellenbosch granitic soil received substantially less water due to its coarse texture and high gravel content (Mulidzi et al., 2016). During the period that the pot experiment was carried out, the $\mathrm{P}$ content in the wastewater obtained from the same winery near Rawsonville, diluted to a COD of $3000 \mathrm{mg} / \mathrm{L}$, was $4.8 \pm 1.6 \mathrm{mg} / \mathrm{L}$ (Howell \& Myburgh, 2014). The amount of 
TABLE 1

Irrigation volume during four simulated seasons in which four different soils were irrigated with diluted winery wastewater.

\begin{tabular}{llllll}
\hline & \multicolumn{3}{c}{ Irrigation applied (mm/season) } \\
Soil & Season 1 & Season 2 & Season 3 & Season 4 & Total \\
\hline Rawsonville sand & 291 & 289 & 287 & 289 & 1156 \\
Lutzville sand & 281 & 282 & 282 & 281 & 1126 \\
Stellenbosch shale & 246 & 250 & 246 & 245 & 987 \\
Stellenbosch granite & 181 & 180 & 184 & 183 & 728 \\
\hline
\end{tabular}

$\mathrm{P}$ applied during irrigation of a field experiment that was irrigated with the diluted wastewater was $1.3 \pm 0.4 \mathrm{~kg} P$ per hectare per irrigation. Based on these results, the annual application would amount to $9.4 \pm 2.6 \mathrm{~kg}$ P per hectare per year if six diluted wastewater irrigations were applied. This indicates that the annual amount of P applied via the diluted wastewater was relatively small.

The initial P contents were $217 \mathrm{mg} / \mathrm{kg}, 6 \mathrm{mg} / \mathrm{kg}$, $8 \mathrm{mg} / \mathrm{kg}$ and $15 \mathrm{mg} / \mathrm{kg}$ in the Rawsonville sand, Lutzville sand, Stellenbosch shale and Stellenbosch granite soils respectively. With the exception of the Rawsonville sand, $\mathrm{P}$ contents in the soils were in line with values normally expected for vineyard soils (Conradie, 1994). The initial P levels in the Rawsonville sand were more than tenfold the maximum of $20 \mathrm{mg} / \mathrm{kg}$ recommended for grapevines in soils containing less than 6\% clay (Conradie, 1994). This was also more than double the $\mathrm{P}$ level at which wheat yields were reduced in a red, sandy soil near Vaalharts (Eloff \& Laker, 1978). It was previously reported that $P$ levels could range between 10 and $400 \mathrm{mg} / \mathrm{kg}$ for the duplex and gradational soils in Australia (Naidu \& Rengasamy, 1993 and references therein). The foregoing confirms that high levels of $\mathrm{P}$ are not uncommon in agricultural soils. Irrigation with municipal water had a minimal effect on the $P$ contents in all of the soils (data not shown). The change in extractable P of the four soils after wastewater irrigation is shown in Fig. 1. The P content in the 10 to $20 \mathrm{~cm}$ layer of the Rawsonville sand only tended to be higher compared to the top layer following the third irrigation with diluted winery wastewater, thereby indicating that attenuation of $\mathrm{P}$ did not occur in the top layer (Fig. 1A). The drastic decline in available $\mathrm{P}$ in the Rawsonville sand during the third season of winery wastewater irrigation (Fig. 1A) was possibly due the formation of stable complexes with constituents in the wastewater from which $\mathrm{P}$ could not be extracted by the Bray II reagent (Eloff \& Laker, 1978). Since no leaching occurred when irrigations were applied (Mulidzi et al., 2016), it could not have contributed to the decline in available P.

In contrast, irrigation with diluted winery wastewater increased soil $\mathrm{P}$ substantially more in the 0 to $10 \mathrm{~cm}$ layer compared to the 10 to $20 \mathrm{~cm}$ layer of the Lutzville sand and the Stellenbosch granite soil over the four simulated seasons (Fig. 1B \& 1D). This trend indicates that $\mathrm{P}$ attenuation occurred in the top layer of these soils. The very large increase in plant-available $\mathrm{P}$ in the top layer of the very sandy red soil from Lutzville is striking. It confirms the ability of non-acid red sandy soils to retain applied $\mathrm{P}$ in plant-available forms, as reported by others (e.g. Eloff \& Laker, 1978). On the one hand there is little movement of $\mathrm{P}$ in the soil, but there is also little fixation of $\mathrm{P}$ into unavailable forms. Available P in the Lutzville sand increased as the $\mathrm{pH}$ $(\mathrm{KCl})$ increased well above 7 where the diluted wastewater was applied (Fig. 1B). This trend suggests that the increasing amounts of sodium applied via the wastewater increased the soluble $\mathrm{PO}^{3-}$, instead of insoluble calcium phosphates being formed. Although the $\mathrm{P}$ content in the 10 to $20 \mathrm{~cm}$ layer of the Stellenbosch shale tended to be lower after the first simulated season, it increased at the same rate over time as in the 0 to $10 \mathrm{~cm}$ layer (Fig. 1C). This indicates that no $\mathrm{P}$ attenuation occurred from the second season onwards.

In the case of the initially acidic Stellenbosch shale and granite soils (Fig. 1C \& 1D), the amorphous $\mathrm{Fe}^{3+}$ and $\mathrm{Al}^{3+}$ phosphates became more soluble as the $\mathrm{pH}_{(\mathrm{KCl})}$ increased towards the optimum, as proposed by Busman et al. (2002). Since $\mathrm{P}$ was not determined in the irrigation water, models to estimate the effect of irrigation with diluted winery wastewater on soil $\mathrm{P}$ based on the amounts applied could not be created. However, the general variation in available $P$ for the four soils could be illustrated with a plot of relative $\mathrm{P}$, as calculated for each soil and layer, against $\mathrm{pH}_{(\mathrm{KCl})}$ (Fig. 2).

After the fourth season, available P in the Rawsonville sand was still above the norm of $20 \mathrm{mg} / \mathrm{kg}$ proposed by Conradie (1994) for grapevines in sandy soils (Fig. 1A). However, this must be regarded as an atypical situation due to the initially high levels. After four simulated seasons of irrigation with the winery wastewater, Bray II P in the Lutzville sand reached over $40 \mathrm{mg} / \mathrm{kg}$, thus far exceeding the norm of $20 \mathrm{mg} / \mathrm{kg}$ (Fig. 1B). This indicates that the winery wastewater is a good source of $\mathrm{P}$ on such soils. On the other hand, the fact that the Bray II P content of this soil increased by nearly $40 \mathrm{mg} / \mathrm{kg}$ after four seasons could serve as a warning that long-term continuous application of winery wastewater could cause the accumulation of excessive $\mathrm{P}$ levels in such soil over time. After the fourth season, $\mathrm{P}$ in the Stellenbosch shale soil (Fig. 1C) was well below the norm of $30 \mathrm{mg} / \mathrm{kg}$ for grapevines in soils containing more than $15 \%$ clay (Conradie, 1994). The much smaller increases in available $\mathrm{P}$ in the two Stellenbosch soils indicate much larger $P$ fixation into unavailable forms in these acidic soils than in the Lutzville soil. Likewise, $\mathrm{P}$ in the Stellenbosch granite soil (Fig. 1D) was less than the lower threshold of $25 \mathrm{mg} / \mathrm{kg}$ for soils containing $6 \%$ to $15 \%$ clay (Conradie, 1994). The much smaller increases in available $\mathrm{P}$ in the two Stellenbosch soils indicate much larger P fixation into unavailable forms in these acidic soils than in the Lutzville soil. Although the lower thresholds were not reached, this situation does not rule out the possibility that it could be achieved if diluted winery wastewater was applied over a longer period. However, if 

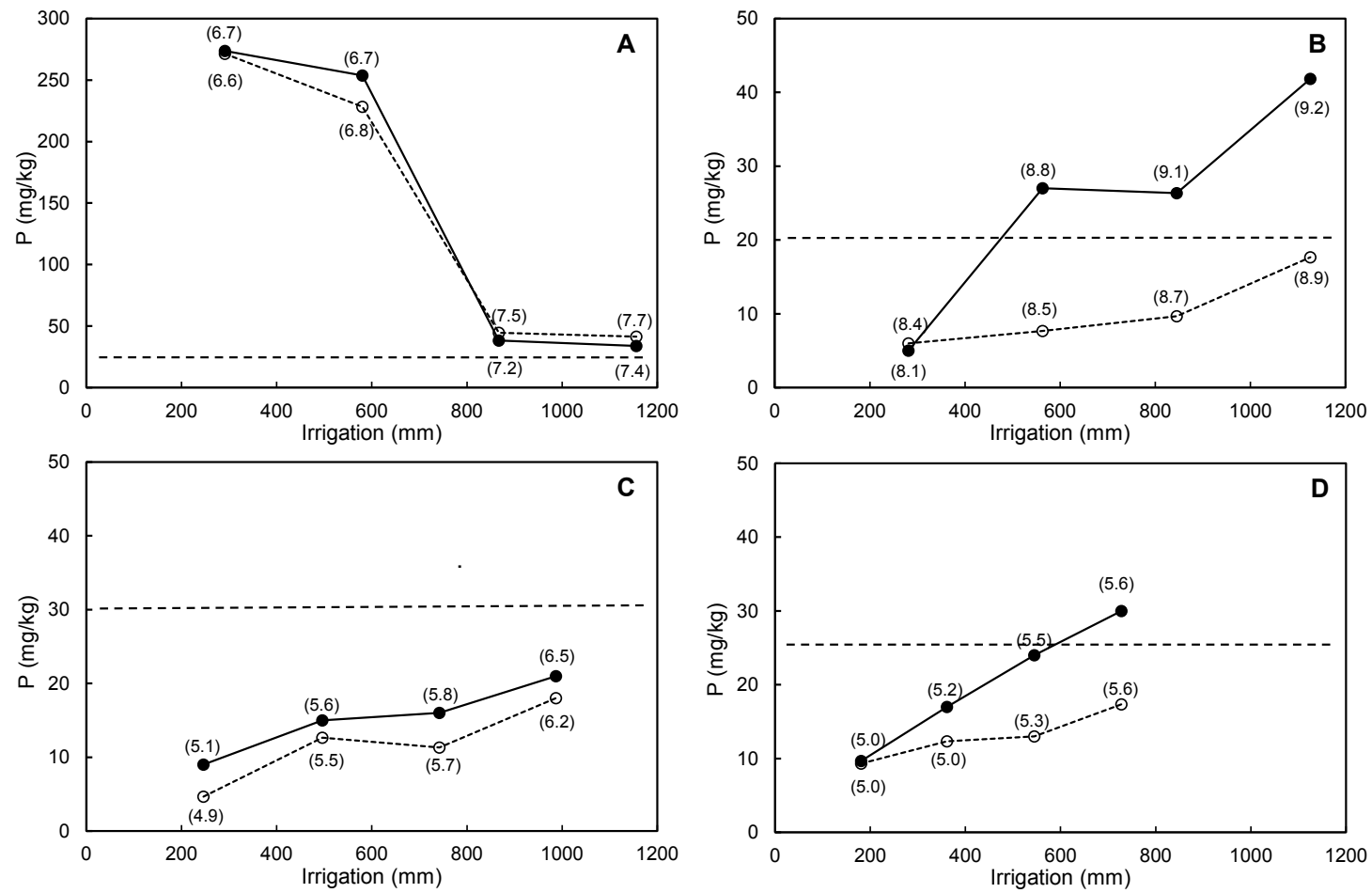

FIGURE 1

Effect of irrigation with diluted winery wastewater on P (Bray 2) in the 0 to $10 \mathrm{~cm}$ layer (solid circles) and 10 to $20 \mathrm{~cm}$ layer (open circles) in (A) Rawsonville sand, (B) Lutzville sand, (C) Stellenbosch shale and (D) Stellenbosch granite soils over four simulated seasons. Values in brackets indicate the soil $\mathrm{pH}_{(\mathrm{KCl})}$. Dashed lines indicate the P (Bray 2) thresholds for grapevines based on clay content (Conradie, 1994).
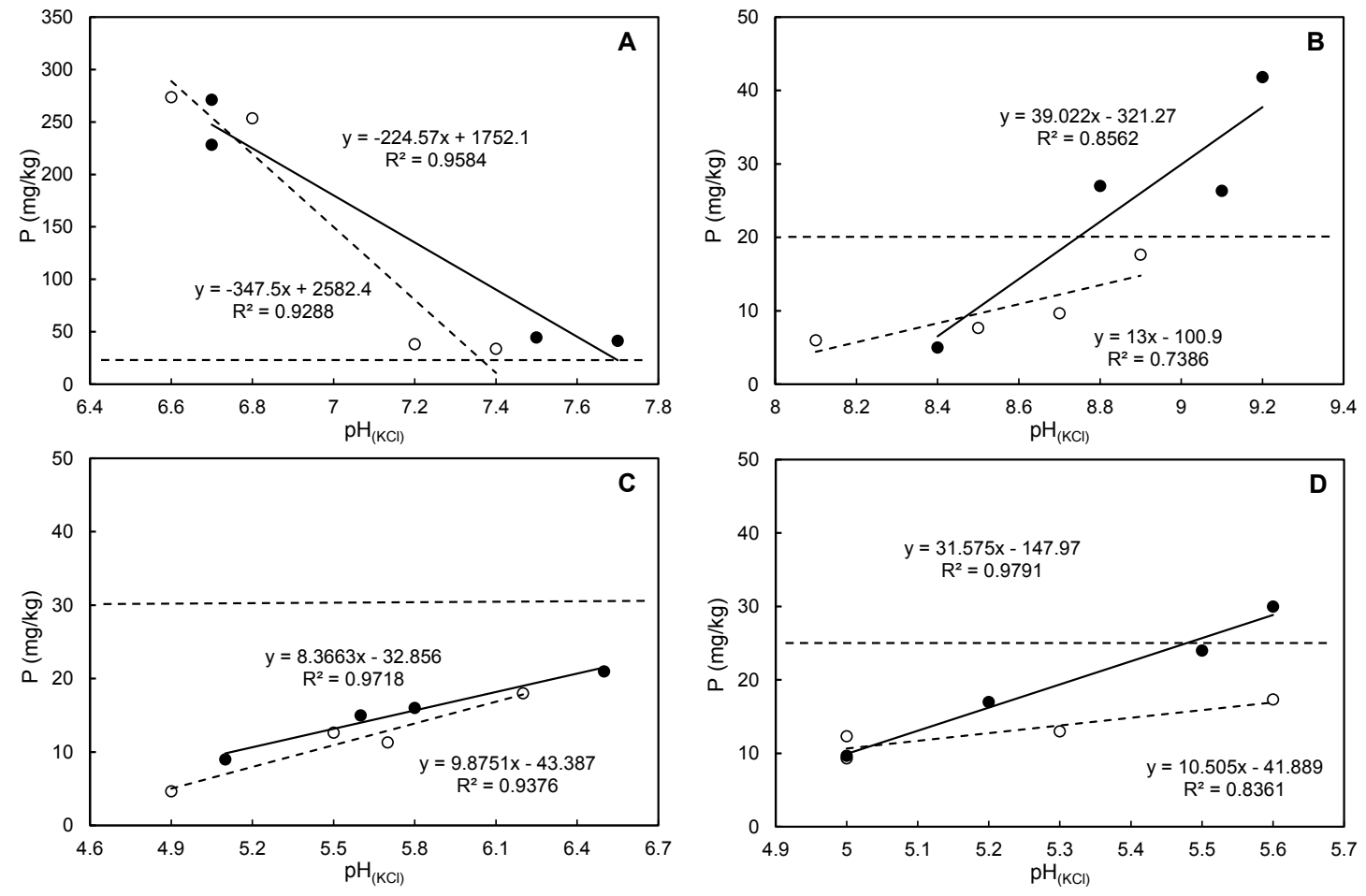

FIGURE 2

Relationship between $\mathrm{P}$ (Bray 2) and $\mathrm{pH}_{(\mathrm{KCl})}$ in the 0 to $10 \mathrm{~cm}$ layer (solid circles) and 10 to $20 \mathrm{~cm}$ layer (open circles) in (A) Rawsonville sand, (B) Lutzville sand, (C) Stellenbosch shale and (D) Stellenbosch granite soils following irrigation with diluted winery wastewater over four simulated seasons. Dashed lines indicate the P (Bray 2) thresholds for grapevine based on clay content (Conradie, 1994). 
the $\mathrm{P}$ applied via winery wastewater were to be absorbed by grapevines and cover crops, the minimum thresholds might not be exceeded to the extent that no fertilisers will be required.

\section{CONCLUSIONS}

Where diluted winery wastewater was applied, the level of soluble $\mathrm{P}$ in the shale and granite soils increased. Although the initial $\mathrm{pH}_{(\mathrm{KCl})}$ in the aeolic sand was higher than the optimum range, the presence of relatively high levels of $\mathrm{Na}^{+}$caused available $\mathrm{P}$ to increase as the $\mathrm{pH}_{(\mathrm{KCl})}$ increased. In the case of the alluvial sand containing unusually high initial levels of $\mathrm{P}$, the $\mathrm{pH}_{(\mathrm{KCl})}$ increased out of the optimum range, thereby causing a substantial reduction in the level of available $\mathrm{P}$. These results indicate that irrigation with diluted winery wastewater could promote $\mathrm{P}$ absorption by grapevines if the $\mathrm{pH}_{(\mathrm{KCl})}$ shift is towards the optimum. Since the level of $\mathrm{P}$ applied via diluted winery wastewater appears to be generally low, the application of $\mathrm{P}$ fertilisers will probably still be necessary to ensure adequate uptake by grapevines. It should be noted that the results represent a worst-case scenario, i.e. in the absence of rainfall or crops. Determining the effect of seasonal leaching by winter rainfall on the chemical status in soils irrigated with diluted winery wastewater is part of an ongoing study.

\section{LITERATURE CITED}

Abrol, I.P., Yadav, J.S.P. \& Massoud, F.I., 1988. Salt affected soils and their management. FAO Soils Bulletin 39, FAO, Rome.

Arienzo, M., Christen, E.W., Jayawardane, N.S. \& Quayle, W.C., 2012. The relative effects of sodium and potassium on soil hydraulic conductivity and implications for winery wastewater management. Geoderma 173-174, $303-$ 310.

Arienzo, M., Quayle, W.C., Christen, E. \& Jayawardane, N., 2009. Irrigating with winery wastewater? Developing soil stability thresholds and managing total cations. Aust. N.Z. Grapegrow. Winemak. October 86-88.

Bond, W.J., 1998. Effluent irrigation - an environmental challenge for soil science. Aust. J. Soil Res. 36, 543-555.

Bueno, P.C., Rubi, J.A.M., Gimenez, R.G. \& Ballesta, R.J., 2009. Impacts caused by the addition of wine vinasse on some chemical and mineralogical properties of a luvisol and a vertisol in La Mancha (Central Spain). J. Soils Sedim. 9, 121-128.

Busman, L., Lamb, J., Randall, G., Rehm, G. \& Schmidt, M., 2002. The nature of phosphorus in soils. University of Minnesota Extension, St Paul.

Christen, E.W., Quayle, W.C., Marcoux, M.A., Arienzo, M. \& Jayawardane, N.S., 2010. Winery wastewater treatment using the land filter technique. J. Environ. Manage. 91, 1665-1673.

Conradie, W.J., 1994. Vineyard fertilization. ARC-Fruit, Vine and Wine Research Institute, Private Bag X5026, Stellenbosch 7599, South Africa.

Department of Water Affairs, 2013. Revision of general authorisations in terms of Section 38 of the National Water Act, 1998 (Act No. 36 of 1998), No. 665. Government Gazette No. 36820, 6 September. Dept. Water Affairs, Pretoria, South Africa, 3-31.

Devau, N., Le Cadre, E., Hinsinger, P., Jaillard, B. \& Gerard, F., 2009. Soil $\mathrm{pH}$ controls the environmental availability of phosphorus: Experimental and mechanistic modelling approaches. App. Geochem. 24, 2163-2174.
Eloff, J.F. \& Laker, M.C., 1978. Phosphorus studies on Vaalharts soil. II The evaluation of method of extraction by correlation of results with various wheat crop parameters. Agrochemophysica 10, 19-23.

Howell, C.L. \& Myburgh, P.A., 2014. Effect of irrigation with augmented winery wastewater on soil chemical status. In: Myburgh, P.A. \& Howell, C.L. (eds). The impact of wastewater irrigation by wineries on soil, crop growth and product quality. Water Research Commission Report No. 1881/14. Private Bag X03, Gezina, South Africa, 0031.

Jalali, M., Merikhpour, H., Kaledhonkar, M.J. \& Van der Zee, S.E.A.T.M., 2008. Effects of wastewater irrigation on soil sodicity and nutrient leaching in calcareous soils. Agr. Water Manage. 95, 143-153.

Laurenson, S. \& Houlbrooke, D., 2011. Winery wastewater irrigation the effect of sodium and potassium on soil structure. Report prepared for Marlborough District Council. Agresearch. 1-22.

Laurenson, S., Bolan, N.S., Smith, E. \& McCarthy, M., 2010. Changes in the cation composition of a Barossa chromosol irrigated with wastewaters of contrasting monovalent cation concentrations. Proc. $19^{\text {th }}$ World Congress of Soil Science (Soil solutions for a changing world), August 2010, Brisbane, Australia.

Laurenson, S., Bolan, N.S., Smith, E. \& McCarthy, M., 2012. Review: Use of recycled wastewater for irrigating grapevines. Aust. J. Grape and Wine Res. 18, 1-10.

Lieffering, R.E. \& McLay, C.D.A., 1996. Effects of high pH solutions with large monovalent cation concentrations on cation exchange properties. Aust. J. Soil Res. 34, 229-242.

Mosse, K.P.M., Patti, A.F., Christen, E.W. \& Cavagnaro, T.R., 2011 Review: Winery wastewater quality and treatment options in Australia. Aust. J. Grape Wine Res. 17, 111-122.

Mulidzi, A.R., 2001. Environmental impact of winery effluent in the Western and Northern Cape Provinces. Thesis, University of Pretoria, Private Bag X20, 0028 Hatfield, Pretoria, South Africa.

Mulidzi, A.R., Clarke, C.E. \& Myburgh, P.A., 2015. Effect of irrigation with diluted winery wastewater on cations and $\mathrm{pH}$ in four differently textured soils. S. Afr. J. Enol. Vitic. 36, 400-410.

Mulidzi, A.R., Clarke, C.E. \& Myburgh, P.A., 2016. Design of a pot experiment to study the effect of irrigation with diluted winery wastewater on four differently textured soils. Water SA 42, 20-25.

Mulidzi, A.R., Laker, G., Wooldridge, J. \& Van Schoor, L., 2009. Composition of effluents from wineries in the Western and Northern Cape Provinces (Part 1): Seasonal variation and differences between wineries. Winetech Technical Yearbook 2009/10, 58-61.

Naidu, R. \& Rengasamy, P., 1993. Ion interaction and constraints to plant nutrition in Australian sodic soils. Aust. J. Soil Res. 31, 801-819.

Oron, G., Campos, C., Gillerman, L. \& Salgot, M., 1999. Wastewater treatment, renovation and reuse for agricultural irrigation in small communities. Agr. Water Manage. 38, 223-234.

Ott, R.L., 1998. An introduction to statistical methods and data analysis. Duxbury Press, Belmont, California.

Papini, A.G., 2000. Land treatment of grape processing effluents near Robertson, Western Cape. Thesis, University of Cape Town, Private Bag X3, 7701 Rondebosch, Cape Town, South Africa.

SAS, 2008. SAS Version 9.2, SAS Institute, Campus Drive, Cary, North Carolina 27513.

Shapiro, S.S. \& Wilk, M.B., 1965. An analyses of variance test for normality (complete samples). Biometrika 52, 591-611.

Sharpley, A.N., Curtin, D. \& Syers, J.K., 1988. Changes in waterextractability of soil inorganic phosphate induced by sodium saturation. Soil Sci. Soc. Am. J. 51, 637-640. 
Van Schoor, L.H., 2001. A formula for the quantification and prioritization of negative environmental impacts in the wine industry. Wineland May, 100-102.

Van Schoor, L.H., 2005. Guidelines for the management of wastewater and solid waste at existing wineries. Winetech, P.O. Box 528, Paarl, 7624.
Walker, C.W. \& Lin, H., 2008. Soil property changes after four decades of irrigation: A landscape perspective. Catena 73, 63-74. 